\title{
Water research and collaboration in the Southern African Development Community
}

\author{
Anastassios Pouris ${ }^{1 *}$ \\ ${ }^{1}$ Institute for Technological Innovation, University of Pretoria, South Africa
}

\begin{abstract}
This article investigates water-related research in the Southern African Development Community. Water issues are part of the region's science and technology priorities as 4countries receive less rain than the global average of $860 \mathrm{~mm} / \mathrm{yr}$ - Botswana with 400 $\mathrm{mm} / \mathrm{yr}$, Namibia with $254 \mathrm{~mm} / \mathrm{yr}$, South Africa with $497 \mathrm{~mm} / \mathrm{yr}$ and Zimbabwe with $652 \mathrm{~mm} / \mathrm{yr}$. Furthermore, the international literature indicates that joint or internationally coordinated research has the potential to improve the scientific-technical quality of international agreements, prevent conflict and shape the way for appropriate management of the shared resources. Scientometric analysis using the Web of Science database is employed in order to identify the state of water research and collaboration in the SADC region. The Web of Science indexes a defined set of journals worldwide and the South African Government provides incentives/subsidies for publications indexed by this database. The results show that South Africa is the main producer (80\%) of research publications in the region. Similarly, in the field of water research South Africa produces $75 \%$ of the region's research. The SADC collaboration matrix in water-related research reveals that there is minimal, if any, collaborative research on the topic. Some seed-level research exists between South Africa, Zimbabwe and Namibia. The main funders of research are the South African National Research Foundation (NRF) (acknowledged in 180 publications), the Bill \& Melinda Gates Foundation (72 publications), the National Institutes of Health (64 publications) and the Wellcome Trust (60 publications). Policy implications are discussed (e.g. the establishment of SADC Common Water Research Area; research support for the region, etc.).
\end{abstract}

Keywords: bibliometrics, SADC, collaboration, scientometrics, research, Web of Science

\section{INTRODUCTION}

The Southern African Development Community is a Regional Economic Community consisting of 15 member countries. A number of countries are small in terms of population. For example, Lesotho, Mauritius, Namibia and Swaziland have populations around or below 2 million (CIA, 2017). SADC is committed to regional integration and eradication of poverty in the member countries. The Regional Indicative Strategic Development Plan (2001) presents a list of priority intervention areas, including the topic 'Science and Technology'. This article aims to analyse a priority area under the topic of 'Science and Technology', viz., water research in the SADC region. Water scarcity, together with the need to ease the disease burden and enhance food security, is among the priority areas shared by the whole of the African continent (Pouris et al., 2014).

A number of articles have investigated the state of research in Africa in general (Narvaez-Berthelemot et al., 2002; Pouris et al., 2014); research in the SADC region (Pouris 2010); the performance of research on water in Africa (Wambu et al., 2016); and water research in South Africa (Jacobs et al., 2014; Siebrits et al., 2014). This article aims to focus on the performance of water research in the SADC region.

Water is of particular importance in the SADC region. Four countries in the region are on the 'wrong side' of the global average isohyet of $860 \mathrm{~mm} / \mathrm{yr}$ - Botswana with $400 \mathrm{~mm} / \mathrm{yr}$, Namibia with $254 \mathrm{~mm} / \mathrm{yr}$, South Africa with $497 \mathrm{~mm} / \mathrm{yr}$ and Zimbabwe with $652 \mathrm{~mm} / \mathrm{yr}$ (Turton, 2010). Furthermore, the mainland SADC states are linked by 21 river basins that cross international borders and there are 22 known transboundary

\footnotetext{
* To whom all correspondence should be addressed.

e-mail:anastassios.pouris@up.ac.za; apouris@icon.co.za

Received 3 July 2017; accepted in revised form 11 June 2018
}

aquifer systems. All water resources require expertise for their management but transboundary water resources require particular expertise for their appropriate management and relevant collaboration among water-sharing states.

During 2012 the Intelligence Community Assessment (2012) investigated how water issues will affect USA interests up to the year 2040. About Southern Africa the report mentions: 'almost certainly will suffer a decrease in water resources due to climate change'. In addition, the report concludes that 'During the next 10 years, many countries important to the United States will experience water problems-shortages, poor water quality, or floods-that will risk instability and state failure, increase regional tensions, and distract them from working with the United States on important US policy objectives. Between now and 2040, fresh water availability will not keep up with demand, in the absence of more effective management of water resources. Water problems will hinder the ability of key countries to produce food and generate energy, posing a risk to global food markets and hobbling economic growth. As a result of demographic and economic development pressures, North Africa, the Middle East, and South Asia will face major challenges coping with water problems' (p. 3). Similar arguments have been developed in a variety of other government documents (e.g. DEA, 2012).

In the above context, research is of critical importance (e.g. RSA, 2012; DEA, 2012). UNESCO, among the 'key messages on promoting cooperation and preventing conflicts in international freshwater management' (Mostert, 2003), argues that joint or internationally coordinated research can improve the scientific-technical quality of international agreements, prevent conflict and shape the way for appropriate management of the shared resources. The issue has attracted a substantial literature (AAAS, 2009; Frankena, 1988; Jasanoff, 1990) and is the subject of a separate investigation. 


\section{METHOD}

Following international best practice evaluative scientometric analysis was employed in order to identify the state of scientific/ research capabilities related to water research in the SADC region.

Similarly, scientometrics was used in order to identify the existing collaborative efforts between South African researchers and those in neighbouring countries, across all scientific disciplines in general, and in water-related research in particular (co-authorship analysis).

Scientometrics is a tool by which the state of science and technology can be observed, through the overall production of scientific literature at a given level of specialization. It is a well-developed scientific discipline (Pouris, 2012) with its own journals (e.g. International Journal of Scientometrics) and international conferences. It provides an approach for situating a country in relation to the world, an institution in relation to a country and even individual scientists in relation to their peers. Scientometric indicators are equally suitable for macro-analysis (e.g. a given country's share in global output of scientific literature over a specified period) and micro-studies (e.g. a given institute's role in producing articles in a particular field or specialty of science).

Scientometric analysis requires the availability of a relevant database. For this investigation we use the Web of Science. The Web of Science - one of the Thomson Reuters databases - covers a defined set of journals worldwide, and the South African Government provides incentives/subsidies for publications indexed by this database. The databases cover different types of documents such as articles, proceedings papers; book chapters; meeting abstracts; editorial material, etc., and covers all scientific disciplines including social sciences and humanities. Inclusion of a journal in the Web of Science follows an evaluation and selection process based on criteria such as contribution to research, citation impact, timeliness of publication, and bibliographic standards (Clarivate Analytics, 2018).

It should be noted that other types of collaborations and outputs exist that are not captured in peer-reviewed publications but these were beyond the scope of this study.

The WoS database classifies the indexed journals according to scientific research areas (e.g. immunology; agriculture; virology etc). For this investigation we utilise the research area classified by the WoS as 'water resources' in order to identify the water-related articles.

\section{RESULTS}

Table 1 shows the number of papers produced by each country and the number of water-related papers during two 3-year periods - 2002-2004 and 2012-2014. The two periods were chosen in order to identify changes over time. A period of 3 years was chosen in order to smooth annual variations.

South Africa produced the majority of research publications in both periods: $80 \%$ during $2012-2014$ and $81.2 \%$ during the 2002-2004 period. In terms of water-related research South Africa produced $75.5 \%$ of the water-related research during 2012-2014 and 71.8\% during the 2002-2004 period.

Assuming a priori that a broad research domain like 'water' requires at least 50 publications per year (20 to 25 publishing researchers) in order to maintain some 'critical mass' able to provide expertise-based advice, it becomes apparent that only South Africa fulfils this criterion of critical mass.
Table 1 also shows the proportion (\%) of each country's publications that are water-related for the two time periods. It becomes apparent that a number of countries (Zimbabwe, Malawi, Botswana, Mozambique, Namibia, and Swaziland for 2012-2014) produce a proportion of water-related publications that is well above the SADC average of $1.6 \%$ (of all publications). This indicates that where there are low numbers of water-related publications this does not reflect a lack of emphasis on water research but rather a lack of research in general, across all research areas. It should also be noted that Angola, Madagascar and Zambia produce fewer water-related publications than that expected based on the SADC average.

In the USA from 2012-2014, 9677 'water resources' publications were produced, which constituted $0.5 \%$ of the total number of publications. Similarly, in China there were 7741 'water resources' publications out of a total of 960318 , i.e., $0.8 \%$. It is possible that after a certain threshold number, the share of publications made up by 'water resources' publications starts diminishing.

Comparison of the two time periods in Table 1 shows that in the most research-prolific countries (South Africa, Tanzania and Zimbabwe) the share of water publications has declined between the two periods. In South Africa the 'water resources' publications share declined from $2.3 \%$ during 2002-2004 to $1.2 \%$ during 2012-2014. This was the result of the relatively higher rate of growth in the number of non-water-related publications.

It is interesting to view the above figures in the context of the South African research system. During the 2012-2014 period South African researchers produced 45343 publications. The majority of these publications were articles (1 290 or $85.7 \%)$. Other publication types include meeting abstracts (79); review articles (64); book chapters (51); editorial material (38); and proceedings (27). Of the total number of publications, 23581 (52\%) were co-authored with at least one author from another country. Among the co-authored publications only 1505 (6.4\% of the co-authored publications) had at least one co-author from the SADC region. In order to identify the influence of non-African countries in the co-authorship effort we excluded the articles that had at least one nonAfrican co-author. Only 563 publications were identified to be co-authored between South African and SADC co-authors (without non-African co-authors). This is only $2.4 \%$ of the South African publications co-authored with at least one author from another country. Thus it appears that SA-SADC co-authorship activities are fuelled by international efforts involving non-African co-authors.

Tables 2 to 7 focus on South Africa as a dominant publishing partner in the region. Table 2 shows the main countries participating in SA-SADC collaborative efforts. USA authors participated in approximately $31 \%$ of the SA-SADC publications. Among the SADC countries, Zimbabwe is the country that collaborated the most with SA authors (almost $27 \%$ of all co-authored publications during the period), followed by England, Tanzania and Malawi.

The main funders of research as acknowledged in each publication were also identified. Of these, the South African National Research Foundation (NRF) appears most often (180 publications), followed by Bill \& Melinda Gates Foundation (72 publications), NIH (64 publications); Wellcome Trust (60 publications) and BMBF, CNRS and Max Plank Society with 32 publications each. It should be noted that organisations from other SADC countries do not appear among the funders. 


\begin{tabular}{|c|c|c|c|c|}
\hline \multicolumn{5}{|c|}{$\begin{array}{c}\text { TABLE } 1 \\
\text { SADC countries: total number of papers and number of water-rel }\end{array}$} \\
\hline & & 2012-2014 & & 2002-2004 \\
\hline Country & No. of papers & $\begin{array}{l}\text { No. of 'water resources' } \\
\text { papers (\% of all papers in } \\
\text { brackets) }\end{array}$ & No. of papers & $\begin{array}{l}\text { No. of 'water resources' } \\
\text { papers (\% of all papers in } \\
\text { brackets) }\end{array}$ \\
\hline South Africa & 45378 & $702(1.5)$ & 17076 & $395(2.3)$ \\
\hline Tanzania & 2911 & $54(1.8)$ & 950 & $47(4.9)$ \\
\hline Zimbabwe & 1306 & $47(3.5)$ & 792 & $64(8.0)$ \\
\hline Malawi & 1358 & $37(2.7)$ & 417 & $5(1.2)$ \\
\hline Zambia & 1111 & $5(0.4)$ & 278 & $6(2.1)$ \\
\hline Botswana & 943 & $31(3.2)$ & 470 & $15(3.2)$ \\
\hline Congo & 523 & $6(1.1)$ & 158 & $2(1.2)$ \\
\hline Mozambique & 618 & $13(2.1)$ & 144 & $3(2.1)$ \\
\hline Namibia & 531 & $20(3.7)$ & 173 & $5(2.9)$ \\
\hline Mauritius & 481 & $3(0.6)$ & 189 & $1(0.5)$ \\
\hline Angola & 171 & $0(0.0)$ & 31 & $0(0.0)$ \\
\hline Swaziland & 139 & $3(2.1)$ & 46 & $4(8.7)$ \\
\hline Seychelles & 128 & $2(1.5)$ & 37 & $1(2.7)$ \\
\hline Lesotho & 95 & $3(3.1)$ & 26 & $2(7.7)$ \\
\hline Madagascar & 757 & $3(0.4)$ & 226 & $0(0.0)$ \\
\hline Total & 56450 & 929 (1.6) & 21013 & $550(2.6)$ \\
\hline
\end{tabular}

\begin{tabular}{|l|c|c|}
\hline \multicolumn{3}{|c|}{$\begin{array}{c}\text { TABLE 2 } \\
\text { Analysis of co-authorship of South African publications in } \\
\text { the period 2012-2014 having at least one co-author from } \\
\text { the SADC region (total of 1 505 publications) }\end{array}$} \\
\hline Country & $\begin{array}{c}\text { Number of } \\
\text { publications } \\
\text { of SA-SADC } \\
\text { co-authored } \\
\text { publications }\end{array}$ \\
\hline USA & 466 & 30.9 \\
\hline Zimbabwe & 406 & 26.9 \\
\hline England & 365 & 24.2 \\
\hline Tanzania & 267 & 17.7 \\
\hline Malawi & 237 & 15.7 \\
\hline Namibia & 221 & 14.6 \\
\hline Zambia & 188 & 12.5 \\
\hline Botswana & 187 & 12.4 \\
\hline Kenya & 159 & 10.5 \\
\hline France & 143 & 9.5 \\
\hline Australia & 137 & 9.1 \\
\hline
\end{tabular}

Table 3 shows the research areas in which SA and SADC countries collaborate. It becomes apparent that medical and health issues dominate the co-authorship list. 'Water resources' contribute $2.6 \%$ of SA-SADC co-authored publications during the 2012-2014 period.

Table 4 shows the main organisations involved in SA-SADC co-authorship. The University of Cape Town and University of the Witwatersrand top the list with approximately $19 \%$ of the total number of co-authored publications, followed by the Universities of KwaZulu-Natal and Pretoria. The Universities of

\begin{tabular}{|l|c|}
\hline \multicolumn{2}{|c|}{$\begin{array}{c}\text { TABLE 3 } \\
\text { Research areas represented by SA-SADC co-authored } \\
\text { publications, }\end{array}$} \\
\hline Research area & $\begin{array}{c}\text { Number of publications out } \\
\text { of 1 505 }\end{array}$ \\
\hline Infectious diseases & $214(14.2 \%)$ \\
\hline Immunology & $160(10.6 \%)$ \\
\hline $\begin{array}{l}\text { Public environmental } \\
\text { occupational health }\end{array}$ & $131(8.7 \%)$ \\
\hline Environmental sciences ecology & $130(8.6 \%)$ \\
\hline Science technology other topics & $109(7.2 \%)$ \\
\hline Agriculture & $68(4.5 \%)$ \\
\hline Virology & $64(4.2 \%)$ \\
\hline General internal medicine & $62(4.1 \%)$ \\
\hline Geology & $56(3.7 \%)$ \\
\hline Microbiology & $49(3.2 \%)$ \\
\hline Plant sciences & $44(2.9 \%)$ \\
\hline Zoology & $44(2.9 \%)$ \\
\hline Veterinary sciences & $43(2.8 \%)$ \\
\hline Tropical medicine & $41(2.7 \%)$ \\
\hline Astronomy astrophysics & $40(2.6 \%)$ \\
\hline Water resources & $40(2.6 \%)$ \\
\hline Chemistry & $39(2.5 \%)$ \\
\hline
\end{tabular}

Zimbabwe and Malawi are the top contributors to SA-SADC collaboration from the SADC region (outside of South Africa). It is interesting to note that collaboration takes place almost exclusively among co-authors affiliated to universities. 


\begin{tabular}{|l|c|}
\hline \multicolumn{2}{|c|}{ TABLE 4 } \\
Main organisations involved in SA-SADC co-authorship, \\
\hline Organisation & $\begin{array}{c}\text { Number of publications out } \\
\text { of 1 505 }\end{array}$ \\
\hline University of Cape Town & $290(19.2 \%)$ \\
\hline $\begin{array}{l}\text { University of the } \\
\text { Witwatersrand }\end{array}$ & $282(18.7 \%)$ \\
\hline University of KwaZulu-Natal & $235(15.6 \%)$ \\
\hline University of Pretoria & $206(13.6 \%)$ \\
\hline University of Zimbabwe & $194(12.8 \%)$ \\
\hline Stellenbosch University & $161(10.7 \%)$ \\
\hline University of London & $150(9.9 \%)$ \\
\hline University of Malawi & $120(7.9 \%)$ \\
\hline $\begin{array}{l}\text { London School of Hygiene \& } \\
\text { Tropical Medicine }\end{array}$ & $108(7.1 \%)$ \\
\hline University of Namibia & $95(6.3 \%)$ \\
\hline University of Botswana & $90(5.9 \%)$ \\
\hline University of California System & $89(5.9 \%)$ \\
\hline Harvard University & $88(5.8 \%)$ \\
\hline North West University (SA) & $85(5.6 \%)$ \\
\hline University of Zambia & $83(5.5 \%)$ \\
\hline John Hopkins University & $64(4.2 \%)$ \\
\hline
\end{tabular}

TABLE 5

Analysis of co-authorship of South African publications in the period 2012-2014 having at least one co-author from the SADC region and without non-African participants, 2012-2014

\begin{tabular}{|l|c|c|}
\hline Country & $\begin{array}{c}\text { Publications out } \\
\text { of } 563\end{array}$ & \% of total \\
\hline Zimbabwe & 170 & 30.2 \\
\hline Namibia & 89 & 15.8 \\
\hline Botswana & 68 & 12.0 \\
\hline Tanzania & 67 & 11.9 \\
\hline Malawi & 60 & 10.6 \\
\hline Swaziland & 35 & 6.2 \\
\hline Zambia & 29 & 5.1 \\
\hline Mozambique & 27 & 4.8 \\
\hline Mauritius & 23 & 4.0 \\
\hline
\end{tabular}

Table 5 shows the contribution of the various SADC countries in the collaborative efforts between SA and SADC when there are no non-African participants. Zimbabwe is the main contributor with $30.2 \%$ of the total co-authored publications. Comparison of Tables 3 and 6 confirms that the majority of the SA-SADC co-authored publications include non-African participants too.

Table 6 shows the most prolific research areas in the cooperation efforts presented in Table 5. 'Agriculture' and 'Environmental sciences ecology' top the list. 'Water resources' appears $6^{\text {th }}$ in the list (shared position with 'engineering' and 'physics') with 24 publications. It is interesting to note that 'infectious diseases' and 'immunology' that comprised the most
TABLE 6

Research areas represented by SA-SADC co-authored publications with no

non-African co-authors, 2012-2014

\begin{tabular}{|l|c|}
\hline Research area & $\begin{array}{c}\text { Number of publications } \\
\text { out of } 563\end{array}$ \\
\hline Agriculture & $56(9.9 \%)$ \\
\hline Environmental sciences ecology & $44(7.8 \%)$ \\
\hline $\begin{array}{l}\text { Public environmental occupational } \\
\text { health }\end{array}$ & $31(5.5 \%)$ \\
\hline Plant sciences & $30(5.3 \%)$ \\
\hline Mathematics & $25(4.4 \%)$ \\
\hline Engineering & $24(4.2 \%)$ \\
\hline Physics & $24(4.2 \%)$ \\
\hline Water resources & $24(4.2 \%)$ \\
\hline Chemistry & $22(3.9 \%)$ \\
\hline Geology & $22(3.9 \%)$ \\
\hline Infectious diseases & $22(3.9 \%)$ \\
\hline
\end{tabular}

prolific research areas represented by SA-SADC co-authored publications (Table 3) drop down the list when publications with at least one non-African author are excluded (Table 6). When there is no non-African influence the research priorities change. Publications in the fields of 'infectious diseases' and 'immunology' appear to be based on collaborations with nonAfrican researchers.

The main participants in SA-SADC co-authorship in the absence of non-African participants are the University of Cape Town (15.2\%), University of Pretoria (15.1\%), University of Zimbabwe (13.8\%), University of the Witwatersrand (12.7\%), and University of KwaZulu-Natal (12.4\%).

Table 7 shows the number of co-authored publications between SA and each of the various SADC countries during 2012-2014 and 2002-2004. The countries that collaborated most often with South African researchers were Zimbabwe and Tanzania. Comparison between the 2002-2004 and 20122014 periods shows that the number of collaborative articles increased across all countries. It is also apparent that SA-SADC co-authorship in the area of 'water resources' is almost nonexistent. Analysis of the type of publication shows that $78 \%$ are articles. The countries with some minimal collaboration with SA in water research - Zimbabwe and Namibia - are among the most water-constrained countries in the region.

Table 8 shows the collaboration matrix for SADC countries in all research disciplines. The table reveals the countries which tend to collaborate within SADC and their preferences. All countries have a higher number of collaborative publications with South Africa than with any other country in the region.

Table 9 shows the SADC collaboration matrix for waterrelated research. The matrix reveals that there is minimal collaborative research on the topic. Some seed-level research exists between South Africa and Zimbabwe and South Africa and Namibia.

\section{CONCLUSIONS}

This article employs scientometrics in order to assess the state of water research and collaboration in the SADC region. South Africa is identified to dominate the research domain in general 
TABLE 7

Number of co-authored publications (in all fields and in 'water resources') between SA and each of the various SADC countries during 2012-2014 and 2002-2004

\begin{tabular}{|c|c|c|c|c|}
\hline \multirow[b]{2}{*}{$\begin{array}{l}\text { Country involved in co- } \\
\text { authorship with SA }\end{array}$} & \multicolumn{2}{|c|}{ 2012-2014 } & \multicolumn{2}{|c|}{ 2002-2004 } \\
\hline & $\begin{array}{l}\text { No. of co-authored } \\
\text { publications: all fields }\end{array}$ & $\begin{array}{c}\text { No. of co-authored } \\
\text { publications: 'water } \\
\text { resources' }\end{array}$ & $\begin{array}{l}\text { No. of co-authored } \\
\text { publications: all fields }\end{array}$ & $\begin{array}{l}\text { No. of co-authored } \\
\text { publications: 'water } \\
\text { resources' }\end{array}$ \\
\hline Angola & 10 & 0 & 0 & 0 \\
\hline Botswana & 186 & 9 & 50 & 2 \\
\hline Congo & 46 & 0 & 1 & 0 \\
\hline Lesotho & 25 & 0 & 6 & 2 \\
\hline Madagascar & 47 & 0 & 20 & 0 \\
\hline Malawi & 229 & 5 & 0 & 0 \\
\hline Mauritius & 42 & 0 & 21 & 0 \\
\hline Mozambique & 97 & 0 & 51 & 2 \\
\hline Namibia & 221 & 12 & 0 & 0 \\
\hline Seychelles & 13 & 0 & 5 & 0 \\
\hline Swaziland & 60 & 0 & 30 & 3 \\
\hline Tanzania & 265 & 2 & 24 & 1 \\
\hline Zambia & 188 & 0 & 92 & 11 \\
\hline Zimbabwe & 404 & 19 & 15 & 0 \\
\hline
\end{tabular}

\begin{tabular}{|c|c|c|c|c|c|c|c|c|c|c|c|c|c|c|c|}
\hline \multicolumn{16}{|c|}{$\begin{array}{l}\text { TABLE } 8 \\
\text { SADC collaboration matrix }- \text { all publications (2012-2014)1 }\end{array}$} \\
\hline & 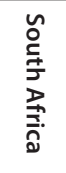 & 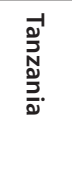 & $\begin{array}{l}N \\
\bar{J} \\
\bar{O} \\
\sum_{0}^{0}\end{array}$ & $\begin{array}{l}\frac{3}{2} \\
\stackrel{0}{2} \\
\underline{2} .\end{array}$ & $\begin{array}{l}\text { N } \\
\frac{N}{3} \\
\frac{\sigma}{2}\end{array}$ & 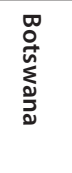 & $\stackrel{\circ}{\circ}$ & 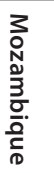 & 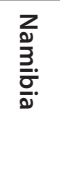 & 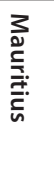 & $\begin{array}{l}\text { 疍 } \\
\text { 을 } \\
\frac{0}{2}\end{array}$ & 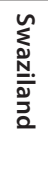 & 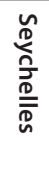 & 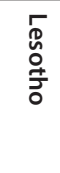 & 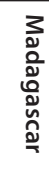 \\
\hline South Africa & & 267 & 406 & 237 & 188 & 187 & 50 & 97 & 221 & 42 & 11 & 60 & 13 & 26 & 47 \\
\hline Tanzania & 267 & & 56 & 54 & 75 & 26 & 9 & 41 & 16 & 3 & 0 & 5 & 3 & 1 & 14 \\
\hline Zimbabwe & 406 & 56 & & 72 & 65 & 32 & 9 & 9 & 16 & 0 & 0 & 3 & 0 & 0 & 4 \\
\hline Malawi & 237 & 54 & 72 & & 51 & 20 & 5 & 23 & 15 & 0 & 0 & 3 & 0 & 4 & 3 \\
\hline Zambia & 188 & 75 & 65 & 51 & & 24 & 12 & 24 & 11 & 1 & 0 & 5 & 0 & 1 & 3 \\
\hline Botswana & 187 & 26 & 32 & 20 & 24 & & 2 & 8 & 15 & 1 & 1 & 3 & 0 & 1 & 0 \\
\hline Congo & 50 & 9 & 9 & 5 & 12 & 2 & . & 2 & 3 & 2 & 1 & 0 & 1 & 0 & 0 \\
\hline Mozambique & 97 & 41 & 9 & 23 & 24 & 8 & 2 & & 8 & 1 & 5 & 3 & 1 & 3 & 4 \\
\hline Namibia & 221 & 16 & 16 & 15 & 11 & 15 & 3 & 8 & & 4 & 4 & 4 & 0 & 3 & 0 \\
\hline Mauritius & 42 & 3 & 0 & 0 & 1 & 1 & 2 & 1 & 4 & & 0 & 0 & 1 & 0 & 7 \\
\hline Angola & 11 & 0 & 0 & 0 & 0 & 1 & 1 & 5 & 4 & 0 & & 0 & 0 & 0 & 0 \\
\hline Swaziland & 60 & 5 & 3 & 3 & 5 & 3 & 0 & 3 & 4 & 0 & 0 & & 0 & 2 & 0 \\
\hline Seychelles & 13 & 3 & 0 & 0 & 0 & 0 & 1 & 1 & 0 & 1 & 0 & 0 & & 0 & 0 \\
\hline Lesotho & 26 & 1 & 0 & 4 & 1 & 1 & 0 & 3 & 3 & 0 & 0 & 2 & 0 & & 0 \\
\hline Madagascar & 47 & 14 & 4 & 3 & 3 & 0 & 0 & 4 & 0 & 7 & 0 & 0 & 0 & 0 & \\
\hline
\end{tabular}

and the field of water research in particular. It is estimated that South Africa is producing $80 \%$ of the region's publications and $75 \%$ of the region's water-related publications. Comparisons of the absolute number of water-related research publications and the share contributed by the field to the countries' total number of publications leads to the conclusion that the issue is not a lack of water research in the SADC region but a lack of research in general. The small number of water-related publications 
TABLE 9

'Water research' collaboration matrix (2012-2014)

\begin{tabular}{|c|c|c|c|c|c|c|c|c|c|c|c|c|c|c|c|}
\hline & 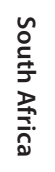 & 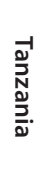 & $\begin{array}{l}N \\
\overline{3} \\
\frac{0}{0} \\
\sum_{0}^{0}\end{array}$ & $\begin{array}{l}\frac{3}{2} \\
\frac{0}{20} \\
\underline{2}\end{array}$ & $\begin{array}{l}\text { N } \\
\frac{N}{3} \\
\frac{0}{Q}\end{array}$ & 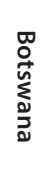 & $\begin{array}{l}\hat{\partial} \\
\stackrel{0}{0}\end{array}$ & $\begin{array}{l}3 \\
3 \\
N \\
\frac{1}{3} \\
\frac{3}{0} \\
\frac{0}{0} \\
\frac{1}{0}\end{array}$ & $\begin{array}{l}\frac{z}{2} \\
\frac{0}{3} \\
\frac{3}{0}\end{array}$ & 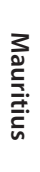 & $\begin{array}{l}3 \\
\text { 뭉 } \\
\frac{0}{2}\end{array}$ & 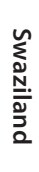 & 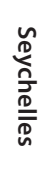 & 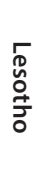 & 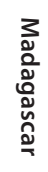 \\
\hline South Africa & & 2 & 19 & 5 & 0 & 9 & 0 & 0 & 12 & 0 & 0 & 0 & 0 & 0 & 0 \\
\hline Tanzania & 2 & & 0 & 0 & 0 & 0 & 0 & 0 & 0 & 0 & 0 & 0 & 0 & 0 & 0 \\
\hline Zimbabwe & 19 & 0 & & 3 & 0 & 2 & 0 & 0 & 7 & 0 & 0 & 0 & 0 & 0 & 0 \\
\hline Malawi & 5 & 0 & 3 & & 0 & 6 & 0 & 0 & 2 & 0 & 0 & 0 & 0 & 0 & 0 \\
\hline Zambia & 0 & 0 & 0 & 0 & . & 0 & 0 & 0 & 0 & 0 & 0 & 0 & 0 & 0 & 0 \\
\hline Botswana & 9 & 0 & 2 & 6 & 0 & & 0 & 0 & 2 & 0 & 0 & 0 & 0 & 0 & 0 \\
\hline Congo & 0 & 0 & 0 & 0 & 0 & 0 & & 0 & 0 & 0 & 0 & 0 & 0 & 0 & 0 \\
\hline Mozambique & 0 & 0 & 0 & 0 & 0 & 0 & 0 & & 0 & 0 & 0 & 0 & 0 & 0 & 0 \\
\hline Namibia & 12 & 0 & 7 & 2 & 0 & 2 & 0 & 0 & & 0 & 0 & 0 & 0 & 0 & 0 \\
\hline Mauritius & 0 & 0 & 0 & 0 & 0 & 0 & 0 & 0 & 0 & . & 0 & 0 & 0 & 0 & 0 \\
\hline Angola & 0 & 0 & 0 & 0 & 0 & 0 & 0 & 0 & 0 & 0 & & 0 & 0 & 0 & 0 \\
\hline Swaziland & 0 & 0 & 0 & 0 & 0 & 0 & 0 & 0 & 0 & 0 & 0 & & 0 & 0 & 0 \\
\hline Seychelles & 0 & 0 & 0 & 0 & 0 & 0 & 0 & 0 & 0 & 0 & 0 & 0 & & 0 & 0 \\
\hline Lesotho & 0 & 0 & 0 & 0 & 0 & 0 & 0 & 0 & 0 & 0 & 0 & 0 & 0 & & 0 \\
\hline Madagascar & 0 & 0 & 0 & 0 & 0 & 0 & 0 & 0 & 0 & 0 & 0 & 0 & 0 & 0 & \\
\hline
\end{tabular}

for the majority of SADC countries may be an indication that these countries do not have the expertise required to meet their research and implementation needs.

Focusing on the co-authorship patterns of South African publications, it is seen that $52 \%$ of South Africa's publication output is in collaboration with authors from other countries. However only $6.4 \%$ of the co-authored publications had at least one co-author from the SADC region and this figure was reduced to $2.4 \%$ when publications with at least one nonAfrican author are excluded. The SADC collaboration matrix for water-related research also reveals that there is minimal, if any, collaborative research on the topic. Some collaborative research exists between South Africa and Zimbabwe and South Africa and Namibia. These findings confirm those of Onyancha et al. (2011) who identified that knowledge production through collaborative research among sub-Saharan African countries is minimal. Zimbabwe is the country collaborating most with SA among the SADC countries (almost $27 \%$ of all co-authored publications during the 2012-2014 period), followed by Tanzania and Malawi.

'Infectious diseases' and 'Immunology' are the research fields displaying the most international (non-African) influence. IntraSADC collaboration (without non-African influence) is focused on 'Agriculture' and 'Environmental sciences ecology'. It can be argued that non-African collaborators have different research priorities to local researchers.

The article identifies the main funders of research as they appear in the acknowledgements sections of the various publications. It is suggested that the various funders can be organised to support water research in the interests of the regional community.

Probably the most important finding of the investigation is the small size of the research systems of the individual countries and as a consequence the likely sub-critical level of expertise in the field of water - an issue of critical importance for the region. The small population size of some countries undoubtedly affects the size of their scientific communities. Lesotho, Mauritius, Namibia and Swaziland, with populations around or below two million, will face a challenge in creating a critical number of researchers in all scientific fields of interest. An alternative will be to aim to create a SADC Common Water Research Area, following the example of the European Common Research Areas. Scientifically small countries will benefit from such an approach. Similarly, countries with larger populations can benefit from the existing infrastructure in the region and South Africa can benefit from the additional human resources in the region. It has been argued (Jacobs et al., 2014) that the institutionalization of water research in South Africa, through the establishment of the Water Research Commission (WRC), has benefited the country, resulting in it being ranked 19th in the world in terms of the output of water research publications while it only places below 30 th in terms of total scientific output. It is suggested that the WRC undertakes to support water research in the SADC region to the benefit of all participating countries including South Africa.

\section{ACKNOWLEDGEMENTS}

This investigation has been supported by the Water Research Commission of South Africa (Project K5/2511). All errors, omissions and conclusions are the author's alone.

\section{REFERENCES}

AAAS (American Association for the Advancement of Science) (2009) American Association for the Advancement of Science Centre for Science Diplomacy: inaugural year in review. AAAS, Washington DC. URL: www.diplomacy.aaas.org/files/CFD_YIR_Web.pdf. (Accessed May 2017) 
CIA (Central Intelligence Agency, USA) (2017) The World Factbook. Central Intelligence Agency. URL: https://www.cia.gov/library/ publications/the-world-factbook/ (Accessed May 2017)

CLARIVATE ANALYTICS (2018) Publication evaluation and selection. URL: http://ipscience-help.thomsonreuters.com/ inCites2Live/indicatorsGroup/aboutHandbook/content/ publication.html(Accessed 11 June 2018).

DEA (Department of Environmental Affairs, South Africa) (2012) $2^{\text {nd }}$ South Africa Environmental Outlook. Department of Environmental Affairs, Pretoria.

FRANKENA F (1988) The emergent social role and political impact of the voluntary technical expert. Environ. Impact Assess. Rev. 8 (1) 73-82. https://doi.org/10.1016/0195-9255(88)90061-3

INTELLIGENCE COMMUNITY ASSESSMENT (2012) Global Water Security ICA 2012-08; 2 February 2012.

JACOBS IM, POURIS A and NAIDOO D (2014) A scientometric examination of the performance of water research in South Africa. Water SA 40 (4) 631-638. 1-7

JASANOFF S (1990) The Fifth Branch; Science Advisers as Policymakers. Harvard University Press, Cambridge, Mass., London.

MOSTERT E (2003) Conflict and Cooperation in the Management of International Freshwater Resources: A Global Review. UNESCO, IHP, WWAP Technical Documents in Hydrology no. 19. Delft University of Technology, Delft, The Netherlands.

NARVAEZ-BERTHELEMOT N, RUSSELL JM, ARVANITIS R, WAAST R and GAILLARD J (2002) Science in Africa: An overview of mainstream Scientific output. Scientometrics 54 229-241. https:// doi.org/10.1023/A:1016033528117

ONYANCHA OB and MALULEKA JR (2011) Knowledge production through collaborative research in sub-Saharan Africa: How much do countries contribute to each other's knowledge output and citation impact? Scientometrics 87 (2) 315-336. https://doi. org/10.1007/s11192-010-0330-5

POURIS A (2010) A scientometric assessment of the Southern Africa Development Community: Science in the tip of Africa. Scientometrics 85 145-154. https://doi.org/10.1007/ s11192-010-0260-2

POURIS A (2012) Scientometric research in South Africa and successful policy instruments. Scientometrics 91 317-325. https:// doi.org/10.1007/s11192-011-0581-9

POURIS A and HO YS (2014) Research emphasis and collaboration In Africa. Scientometrics 98 2169-2184. https://doi.org/10.1007/ s11192-013-1156-8

SADC (Southern African Development Community) (2001) Regional Indicative Strategic Development Plan. URL: http://www.sadc.int/ documents-publications/show/Regional_Indicative_Strategic_ Development_Plan.pdf (Accessed May 2017).

SIEBRITS R, WINTER K and JACOBS I (2014) Water research paradigm shifts in South Africa. S. Afr. J. Sci. 110 (5/6). https://doi. org/10.1590/sajs.2014/20130296

TURTON A (2010) New thinking on the governance water and river basins of Africa: Lessons from SADC region. South African Institute of International Affairs, Johannesburg

RSA (Republic of South Africa) National Development Plan 2030. Government of the Republic of South Africa, Pretoria.

WAMBU EW and HO Y-S (2016) A bibliometric analysis of drinking water research in Africa. Water SA 42 (4) 612-620. https://doi. org/10.4314/wsa.v42i4.12 